Jurnal Interpretasi Hukum |ISSN: 2746-5047

Vol. 2, No. 2 - Agustus 2021, Hal. 346-352| Tersedia online di https://www.ejournal.warmadewa.ac.id/index.php/juinhum DOI: https://doi.org/10.22225/juinhum.2.2.3439.346-352

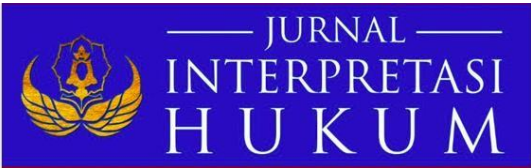

\title{
PELAKSANAAN PERATURAN GUBERNUR BALI NOMOR 97 TAHUN 2018 TENTANG PEMAKAIAN KANTONG PLASTIK SEKALI PAKAI DI KOTA DENPASAR
}

\author{
Gede Putu Oka Brahma Adhi, I Wayan Rideng, Ida Ayu Putu Widiati \\ Fakultas Hukum Universitas Warmadewa, Denpasar, Bali \\ gedeputuoka@yahoo.com, wyrideng@gmail.com, idaayuputuwidiati@gmail.com
}

\begin{abstract}
Abstrak
Masyarakat dan Pemerintah Kota Denpasar berinisiatif untuk menyelamatkan Pulau Bali yang dikenal sebagai Pulau surga terakhir, "The Last Island Paradise" dengan harapan berdampak terhadap pelestarian alam semesta. Reaksi masyarakat terhadap terbitnya Peraturan Daerah Nomor 97 Tahun 2018 sangat beragam. Ada yang setuju lalu memberikan dukungan dengan tindakan nyatga tidak memakai wadah berbahan dasar plastik. Tujuan dari penelitian ini adalah untuk mengungkap faktor penghambat pelaksanaan Peraturan Gubernur Bali Nomor 97 Tahun 2018 terhadap pembatasan kantong plastik sekali pakai di Kota Denpasar dan dampak pelaksanaan Peraturan Gubernur Bali Nomor 97 Tahun 2018 terhadap Perkembangan Pariwisata di Kota Denpasar. Jenis penelitian yang digunakan dalam peneltian ini, adalah jenis penelitian hukum emperis. Berdasarkan penelitian yang telah dilakukan adalah faktor penghambat terlaksananya Peraturan Gubernur Nomor 97 Tahun 2018 tentang Pengurangan Penggunaan Kantong Plastik, antara lain: kurangnya kesadaran masyarakat, minimnya fasilitas untuk mengelola sampah, budaya masyarakat menggunakan kantong plastik masih tinggi, penegakan hukum terhadap Peraturan Wali Kota Denpasar Nomor 36 Tahun 2018 masih lemah.
\end{abstract}

Kata Kunci: Peraturan Gubernur, Kantong Plastik, Kota Denpasar

\begin{abstract}
Abstarct
The community and the Government of Denpasar City took the initiative to save Bali Island, which is known as the last paradise island, "The Last Island Paradise" with the hope of having an impact on preserving the universe. Public reactions to the issuance of Regional Regulation Number 97 of 2018 are very diverse. There are those who agree and then provide support with the real action not to use plastic-based containers. The purpose of this study is to reveal the inhibiting factors for the implementation of Bali Governor Regulation Number 97 of 2018 against the restriction of single-use plastic bags in Denpasar City and the impact of implementing Bali Governor Regulation Number 97 of 2018 on Tourism Development in Denpasar City. The type of research used in this research is empirical law research. Based on the research that has been done, it is an inhibiting factor for the implementation of Governor Regulation Number 97 of 2018 concerning Reducing the Use of Plastic Bags, among others: lack of public awareness, lack of facilities to manage waste, the culture of the community using plastic bags is still high, law enforcement of Denpasar Mayor Regulation Number 36 of 2018 is still weak.
\end{abstract}

Keywords: Governor Regulation, Plastic Bags, Denpasar City. 


\section{PENDAHULUAN}

Indonesia yang akan masuk ke dalam kelompok negara yang sedang berkembang dituntut memiliki persyaratan yang sangat banyak dan sulit untuk dilaksanakan, salah satunya adalah harus mempunyai lingkungan alam yang lestari, indah, dan terjaga dengan baik. Namun apapun itu negara dan masyarakat Indonesia wajib bekerja keras untuk mewujudkan lingkungan daerah yang semakin bersih dan lestari, alam laut dan pegunungan yang indah akan memberikan kontribusi yang sangat besar bagi kehidupan bangsa dan negara. Alam yang sehat akan membantu masyarakat dalam berbagai sektor, seperti sektor ekonomi, pariwisata, hingga ketahanan pangan. Sektor ekonomi dapat kita lihat pada daerah pesisir, yang menggantungkan harapan hidupnya pada keberadaan ikan di lautan. Sektor pariwisata terlihat pada turis-turis asing yang banyak berkunjung ke daerah yang lebih asri dari hiruk pikuk perkotaan. Sektor ketahanan pangan berkaitan erat dengan sektor ekonomi. Keberadaan pangan di alam yang sehat akan terpaut erat dengan permintaan konsumen di pasar. Maka dari itu, menjaga alam tetap sehat dan lestari memunculkan banyak keuntungan di pelbagai sektor.

Tak hanya itu, kehidupan bermasyarakat di Bali erat pula kaitannya dengan filsafat Tri Hita Karana. Filsafat ini mengajak masyarakat untuk lebih peduli terhadap budaya dan lingkungan. Filsafat ini berisikan ajaran bagaimana hubungan manusia dengan manusia lainnya, manusia dengan lingkungannya, dan manusia dengan Tuhan. Hubungan manusia dengan lingkungan memicu masyarakat untuk bertindak menghargai lingkungan sebagai objek yang dapat hidup berdampingan dengan manusia karena dalam filsafat Tri Hita Karana berpandangan bahwa jika manusia dapat hidup berdampingan dengan alam, maka masyarakat akan mendapatkan manfaat-manfaatnya. Jika filsafat ini dipegang teguh oleh masyarakat, tak hanya masyarakat sendiri yang akan menerima dampaknya. Lingkungan akan menjadi lebih lestari sehingga akan kembali memberikan timbal balik yang serupa kepada masyarakat. Serta, dalam filsafat ini masyarakat diajak untuk dapat memandang lingkungan sebagai objek yang memiliki kehidupan alamiahnya. Maka dari itu, selain menjaga lingkungan penting untuk kehidupan bermasyarakat, hal itu selaras pula dengan ajaran Tri Hita Karana yang diyakini masyarakat Bali. Beberapa ilmuwan juga memberikan definisinya terkait alam Indonesia yang perlu dijaga dan dilestarikan untuk mencapai kehidupan yang lebih damai.

Negara Kesatuan Republik Indonesia yang juga dikenal sebagai Nusantara, sungguh sangat mempesona keindahannya. Bagaikan untaian zambrud yang membentang di garis khayal khatulistiwa, sangat indah, elok, nan menawan dipandang mata. Anugerah yang diberikan oleh Tuhan Yang Maha Esa ini, memang tidak ada duanya di dunia, sehingga sekaligus menjadi amanah yang wajib dipelihara oleh seluruh rakyat Indonesia (Gunawan, 2016).

Nuansa alam Nusantara yang indah nan permai ini menjadikan bangsa lain berdecak kagum dan iri hati, lalu berlomba-lomba dengan berbagai cara berusaha mengusai dengan cara menjajah rakyat Nusantara. Sejarah kelam selama tiga ratus lima puluh tahun Nusantara dijajah kaum kolonial adalah bukti keelolakan dan melimpah ruahnya kekayaan alam Nusantara yang tidak ada duanya di dunia sehingga selalu menjadi rebutan negara lain untuk melakukan penjajahan dengan cara neokolonialisme (Janin, 1957)

Menjaga Nusantara adalah amanah Tuhan yang wajib untuk dilaksanakan oleh seluruh "tumpah darah" Indonesia. Hal ini sangat penting dilestarikan keelokannya, jangan sampai Nusantara nan elok permai menjadi kurang nyaman dipandang mata karena masyarakatnya tidak memperhatikan tata cara membuang sampah. Tumpukan sampah yang menggunung di setiap Tempat Pembuangan Akhir sampah atau TPA, sungguh memilukan hati dan sangat mengganggu keindahan dan kenyamanan masyarakat. Lebih menyedihkan lagi, ada perilaku masyarakat yang tidak perduli terhadap bahaya dari sampah plastik yang tidak bisa terurai selama ratusan tahun. Secara sembarangan oknum-oknum tertentu membuang sampah dengan tanpa memilah terlebih dahulu mana sampah plastik yang dikenal sebagai non organic dan mana sampah organik yang bisa diurai oleh bakteri. 
Menjaga alam Indonesia menjadi kewajiban seluruh lapisan masyarakat. Lapisan masyarakat dalam hal ini adalah pula mencakup pemerintah sebagai pembuat aturan di Indonesia. Masyarakat dan pemerintah harus secara proaktif dan sadar dalam menjaga kelestarian alam Indonesia. Dalam kehidupan bernegara pula, himbauan yang dilayangkan pemerintah Indonesia dalam rangka melestarikan alam Indonesia harus berupa peraturan tertulis, lengkap dengan sanksi-sanksi tegas yang tertuang di dalamnya. Hal itu menjadi sebuah keharusan karena jika masyarakat tak diawasi dengan aturan-aturan yang ada, mereka akan bertindak bebas sesuai kepentingannya. Sehingga, cita-cita Indonesia dalam melestarikan alamnya akan menjadi semakin sulit untuk terealisasikan

Karena itulah masyarakat dan Pemerintah Kota Denpasar berinisiatif untuk menyelamatkan wilayah Pulau Bali yang dikenal sebagai pulau surga terakhir, The Last Island Paradise dengan harapan berdampak terhadap pelestarian alam semesta. Gagasan untuk memberikan jaminan keindahan dan kenyamanan untuk masyarakat dan wisatawan yang berkunjung menjadi turis ke Bali dituangkan dalam bentuk regulasi yaitu, Peraturan Derah Bali Nomor 97 Tahun 2018 tentang Pengurangan Penggunaan Kantong Plastik. Reaksi masyarakat terhadap terbitnya Peraturan Daerah Nomor 97 Tahun 2018 sangat beragam. Ada yang setuju lalu memberikan dukungan dengan tindakan nyaga tidak memakai wadah berbahan dasar plastik. Namun demikian tidak sedikit juga yang kurang sependapat dengan diterbitkannya aturan ini karena masyarakat telah terbiasa dengan penggunaan plastik sebagai kantong belanja. Upaya Pemerintah Kota Denpasar dalam rangka untuk mensosialisasikan ketentuan ini sangat banyak, mulai sosialisasi ke banjar-banjar, melalui radio, media massa cetak berupa koran, sampai juga dengan menggunakan media elektronik berupa reklame di televisi. Semuanya sudah dilakukan untuk tujuan agar masyarakat mengetahui, memahami, lalu muncul kesadaran sendiri untuk bersama mengurangi sampah plastik. Kalau diteliti dari kewenangan Gubernur Bali untuk mengeluarkan regulasi tentang pengurangan penggunaan kantong plastik, berdasarkan ketentuan Pasal 4 Peraturan Gubernur Nomor 97 Tahun 2018 secara limitatif ditegaskan dalam rangka menetapkan kebijakan dan strategi pengurangan penggunaan kantong plastik. Selain itu untuk melakukan pembinaan, pengawasan dan evaluasi secara periodik terhadap penggunaan kantong plastik oleh konsumen maupun oleh palaku usaha. Hal ini penting untuk dilakukan agar masyarakat dan pelaku usaha wajib mempergunakan kantong plastik alternatif yang ramah lingkungan untuk keperluan membawa barang belanjaan.

Indonesia adalah negara kedua terbesar setelah Tiongkok penyumbang sampah plastik yang di buang ke laut. Sampah plastik merupakan sampah yang paling banyak dibuang oleh manusia karena banyak orang yang menggunakan plastik untuk keperluannya sehari-hari baik perorangan, toko, maupun perusahaan besar. Pembuangan sampah plastik ke dalam air dan tanah telah menambah tingkat pencemara alam. Apabila ditimbun dalam tanah, butuh waktu berjutajuta tahun hingga sampah plastik tersebut dapat diuraikan. Apabila dibakar berpotensi mengeluarkan dioksin yang berbahaya bagi kesehatan, residu plastik akan menjadi gumpalan, dan butuh waktu lama untuk mengurainya (Nazaruddin Lathif, 2019). Dalam sebuah wawancara yang dilakukan peneliti sebelumnya menemukan sebuah fakta bahwa pada tahapan komunikasi, Pemerintah Kota Bogor telah melaksanakan program yang cukup baik sehingga kebijakan Peraturan Walikota Nomor 61 tahun 2018 ini tersebar massif dimasyarakat dan juga dilaksanakan oleh para pelaksana usaha toko ritel modern (swalayan). Melalui sebuah wawancara dengan salah satu staf pegawai Dinas Lingkungan Hidup dan kebersihan Kota Bogor, beliau memaparkan bahwa : "Kalau untuk proses implementasi kebijakan Peraturan Walikota Bogor Nomor 61 Tahun 2018 tentang Pengurangan Penggunaan Kantong Plastik di kota Bogor ini sebenarnya bertujuan untuk mengurangi dampak sampah terutama sampah plastik di kota Bogor, di mana sasarannya ditujukan kepada pelaku usaha toko ritel modern atau swalayan sebagai penyedia kantong plastik sekali pakai dan juga masyarakat agar dapat mengurangi penggunaan kantong plastik pada saat berbelanja"(Harfin Nurulhaq, 2020). Implementasi hukum terhadap Peraturan Walikota Nomor 36 Tahun 2018 belum dapat dilakukan dengan baik yang dimana pada pelaku usaha di pasar tradisional tidak semua pelaku usaha dapat melakukan kegiatan jual beli tersebut, hal ini dikarenakan tidak semua barang yang diperjual belikan dapat dikemas 
menggunakan kantong alternative. Sebagai contoh pelaku usaha daging segar. Pada pelaksanaannya pelaku usaha daging tersebut biasanya menggunakan kantong plastik sebagai sarana untuk mengkemas daging yang di perjual belikan. Karena dalam hal ini, tidak mungkin dalam proses jual beli daging tersebut pelaku usaha menggunakan tote- bag ataupun paper bag sebagai sarana untuk mengkemas daging tersebut (I Gede Druvananda Abhiseka, \& Nengah Suharta, 2019).

Berdasarkan penjelasan yang telah diuraikan diatas maka tujuan dari penelitian ini untuk mengetahui faktor penghambat pelaksanaan Peraturan Gubernur Bali Nomor 97 Tahun 2018 terhadap pembatasan kantong plastik sekali pakai di Kota Denpasar dan mengetahui dampak pelaksanaan Peraturan Gubernur Bali Nomor 97 Tahun 2018 terhadap Perkembangan Pariwisata di Kota Denpasar.

\section{METODE PENELITIAN}

Jenis penelitian yang digunakan dalam peneltian ini, adalah jenis penelitian hukum emperis. Jenis penelitian hukum emparis yang dipilih karena dianggap sangat relevan untuk meneliti kesenjangan apa yang seharusnya terjadi sebagaimana norma yang mengatur prilaku manusia, dengan kenyataan atau fakta hukum di masyarakat. Secara normatif, seharusnya orang tidak mempergunakan kantong plastik lagi sebagai wadah belanjaan sehari-hari berdasarkan Peraturan Gubernur Bali Nomor 97 Tahun 2018, namun kenyataannya masih saja ada oknum anggota masyarakat yang memakai kantong plastik sebagai tempat membawa barang belanja sehari-hari. Sumber bahan hukum yang digunakan adalah sumber data hukum primer dimana teknik pengumpulan datanya bersumber dari jurnal, literature atau buku. Setelah data terkumpul maka dianalisis secara kualitatif.

\section{PEMBAHASAN}

\section{Pelaksanaan Peraturan Gubernur Bali Nomor 97 Tahun 2018 Tentang Pembatasan Penggunaan Kantong Plastik Sekali Pakai Di Kota Denpasar}

Pariwisata yang tak dapat dipisahkan dari Pulau Bali dan Kota Denpasar sebagai kota terpadat di Bali, dengan berbagai persoalan kompleksnya membawa dampak buruknya. Seperti harga tanah yang meninggi hingga enam kali lipat, melambungnya tingkat pengangguran, merebaknya pekerja sektor informal dan PKL, hingga permasalahan lalu lintas yang hingga saat ini belum dapat diatasi oleh Pemerintah Daerah Kota Denpasar.

Idealnya, perbandingan wilayah di suatu daerah yang terbangun dan yang tak terbangun adalah 40:60. Namun, perbandingan daerah yang terbangun di Kota Denpasar mencapai 70:30 dengan wilayah yang belum terbangun, hal ini dapat dilihat pada peta wilayah dalam RTRW. Walaupun demikian, Pendapatan Domestik Regional Bruto (PDRB) Kota Denpasar, merupakan yang tertinggi kedua di Provinsi Bali. Maka dari itu, pemberlakuan otonomi daerah dapat diberikan kepada Kota Denpasar jika dilihat dari kesiapan finansialnya.

Pulau Bali yang dikenal akan pariwisatanya berusaha untuk lebih ramah terhadap lingkungan. Salah satu aksi nyata yang dilakukan Pemerintah Bali adalah dengan mengeluarkan Peraturan Gubernur Nomor 97 Tahun 2018 perihal penggunaan kantung plastik sekali pakai. Peraturan Gubernur ini muncul akibat dampak negatif dari penggunaan plastic yang harus ditanggung alam karena keberadaannya. Sebagaimana diketahui, sekitar 50 tahun silam plastik mulai digunakan oleh sebagian besar masyarakat dunia. Sekitar 500 juta hingga 1 milyar kantong plastik digunakan masyarakat dunia dalam satu tahun. Untuk membuat kantong plastik diperlukan 12 juta barel minyak per tahun dan 14 juta pohon yang harus ditebang.

Peraturan Gubernur ini mewajibkan setiap pelaku usaha hingga produsen dan distributor untuk menyediakan pengganti kantong plastik sekali pakai. Peraturan ini juga melarang untuk memproduksi, mendistribusikan, memasok, dan menyediakan kantong plastik sekali pakai. Para pelaku usaha, baik produsen hingga pemasok diberikan waktu selama 6 bulan terhitung sejak Peraturan Gubernur ini diundangkan untuk dapat menyesuaikan diri dengan peraturan ini. Tak hanya 
pelaku usaha, instansi pemerintah, BUMD, swasta, lembaga keagamaan, desa/adat, hingga masyarakat juga dilarang untuk menggunakan kantong plastik sekali pakai.

Gubernur Bali, Wayan Koster turut meyakinkan dan mengajak pemerintah daerah lain untuk membuat regulasi dan kebijakan yang sama. Hal itu ia sampaikan demi terwujudnya alam Indonesia yang terbebas dari sampah plastik. Menurut Koster, penerbitan peraturan ini sebagai aksi menjaga lingkungan. Hal ini dilakukannya agar sampah plastik tak menumpuk di TPA. Dalam rencananya, Koster akan melanjutkan kebijakan ini sebagai bentuk pelestarian lingkungan di Bali. Ia berharap persoalan sampah dapat terselesaikan di hulu, sehingga TPA tak lagi menampung banyak sampah

\section{Dampak Penggunaan Kantong Plastik Terhadap Perkembangan Pariwisata Di Kota Denpasar}

Suatu himpunan bidang usaha yang memproduksi berbagai macam jasa serta benda yang diperlukan oleh mereka yang melakukan ekspedisi wisata dikenal dengan Industri pariwisata. Berbagai produk, baik yang nyata maupun maya disajikan guna memenuhi kebutuhan manusia dapat dinilai sebagai produk industri. United Nations World Tourism Organization (UNWTO), dalam International Recommendations for Tourism Statistics 2008, mengemukakan bahwasannya industri pariwisata meliputi; Akomodasi bagi wisatawan, aktivitas layanan santapan serta minuman, angkutan penumpang, agen ekspedisi wisata, aktivitas reservasi, aktivitas budaya, aktivitas berolahraga, hingga aktivitas hiburan.

Sampah plastik yang sulit diurai oleh alam menjadi ancaman bagi lingkungan, khususnya lingkungan alam Pulau Bali. Musababnya tentu pada sampah plastik telah menyebar di berbagai daerah, baik daerah pesisir maupun daerah dataran tinggi. Hal ini menjadi ancaman bagi Pulau Bali yang menjadi zona destinasi wisata di Indonesia.

Diterbitkannya peraturan ini berguna untuk pembatasan sampah plastik di wilayah Bali. Pemerintah daerah pun merespon positif dengan terbitnya Peraturan Gubernur ini, ialah Wali Kota Denpasar yang menandatangani Perwali Nomor 36 Tahun 2018 tentang pemakaian sampah plastik di Denpasar. Terdapat tiga bahan yang dilarang dalam Peraturan Gubernur Bali ini, ialah kantong plastik, polysterina ataupun Styrofoam, serta sedotan berbahan dasar plastik. Koster pula telah menginstruksikan pihak terkait melalui surat edaran mengenai Peraturan Gubernur tentang pembatasan sampah plastik. Musababnya karena sampah non-organik telah mengancam kelestarian di Pulau Bali

Sebagai wujud apresiasi kepada lembaga pemerintahan, BUMD, swasta, lembaga keagamaan, lembaga sosial, desa adat maupun pekraman, hingga masyarakat, Pemerintah Bali hendak membagikan penghargaan untuk mereka yang taat menjalankan Peraturan Gubernur tersebut. Kadis Area Hidup serta Kebersihan (DLHK) di Kota Denpasar, Ketut Wisada menerangkan bahwa ia bersama staff DLHK menggencarkan sosialisasi kepada pedagang di pasar tradisional dan toko modern untuk mempersiapkan kantong ramah lingkungan, serta terkhusus untuk swalayan agar mempersiapkan kantong tersebut jika ada konsumen yang tidak membawa kantong dari rumah.

Begitu pula sebaliknya, Pemerintah Bali hendak memberikan sanksi tegas untuk mereka yang tidak mematuhi syarat dalam Peraturan Gubernur tersebut. Bagi mereka yang tidak mematuhi peraturan ini akan dikenakan sanksi tertulis sesuai aturan yang berlaku. Sekretaris DLHK Kota Denpasar, Ida Bagus Putra Wirabawa berkata bahwa timnya sudah melaksanakan sosialisasi pengurangan kantong plastik dengan cara memfasilitasi pembeli dengan tas belanja ramah lingkungan di Denpasar, salah satunya Pasar Kreneng. Hal itu dilakukan oleh Wirabawa dalam rangka menunjang sosialisasi serta pelaksanaan Perwali Kota Denpasar. Ia berkata bahwa staffnya telah membagikan tas belanja kepada masyarakat yang belum mematuhi peraturan ini. Sedikitnya, sekitar 400 kantong belanja ramah lingkungan telah dibagikan oleh DLHK Kota Denpasar. Sosialisasi ini Ia lakukan dengan tujuan membimbing warga untuk turut mengurangi sampah plastik dan menggantinya dengan 
bahan yang dapat didaur ulang. Tak hanya hal itu, pemakaian tas belanja ramah lingkungan dapat mengurangi pemakaian kantong plastik.

Manajer Alfamart, Mohammad Sofii mengatakan juga bahwa staffnya sedang melaksanakan sosialisasi kepada pengunjung toko mengenai pemberlakuan Perwali Kota Denpasar bahwa terhitung sejak tanggal 1 Januari 2019, Pemerintah Kota Denpasar melarang penggunaan kantong plastik di toko-toko modern sebagai upaya pengurangan sampah plastik. Pemerintah Kota Denpasar telah secara proaktif untuk melaksanakan sosialisasi kepada masyarakat. Caranya pun beragam hingga memasang baliho atau spanduk mengenai Perwali tersebut. Dampak pelaksanaan Peraturan Gubernur Nomor 97 Tahun 2018 kepariwisataan di Bali sangat baik. Adapun indikatornya adalah: Kebersihan dan keindahan Kota Denpasar semakin bersih karena sampah plastik secara signifikan berkurang. Kunjungan wisatawan jumlahnya semakin meningkat untuk berkunjung ke Kota Denpasar karena wajah kota semakin bersih, asri, dan indah. Pembangunan insfrastruktur semakin meningkat, terutama fasilitas kepariwisataan untuk memberikan jaminan kenyamanan dan keamanan bagi para wisatawan.

Investasi semakin meningkat karena iklim yang sudah tercipta semakin kondusif karena adanya pengurangan sampah berbahan dasar plastik.

\section{SIMPULAN DAN SARAN}

\section{Simpulan}

Berhubungan dengan paparan di atas, maka disimpulkan faktor penghambat terlaksananya Peraturan Gubernur Nomor 97 Tahun 2018 tentang Pengurangan Penggunaan Kantong Plastik, antara lain: Kurangnya kesadaran masyarakat, karena kurang beratnya sanksi yang diberikan dan beberapa dinas sosial masih kurang tegas dalam menindaklanjuti pelaku.Minimnya fasilitas untuk mengelola sampah. Budaya masyarakat menggunakan kantong plastik masih tinggi. Penegakan hukum terhadap Peraturan Wali Kota Denpasar Nomor 36 Tahun 2018 masih lemah. Dampak Pelaksanaan Peraturan Gubernur Nomor 97 Tahun 2018 kepariwisataan di Kota Denpasar sangat baik. Adapun indikatornya adalah: Kebersihan dan keindahan Kota Denpasar semakin bersih karena sampah plastik secara signifikan berkurang. Kunjungan wisatawan jumlahnya semakin meningkat untuk berkunjung ke Kota Denpasar karena wajah kota semakin bersih, asri, dan indah. Pembangunan insfrastruktur semakin meningkat, terutama fasilitas kepariwisataan untuk memberikan jaminan kenyamanan dan keamanan bagi para wisatawan. Investasi semakin meningkat karena iklim yang sudah tercipta semakin kondusif karena adanya pengurangan sampah berbahan dasar plastik.

\section{Saran}

Berhubungan dengan simpulan tersebut di atas maka dapat disampaikan saran yaitu masyarakat Kota Denpasar, serta pengunjung atau wisatawan yang datang ke Kota Denpasar untuk berperan aktif mengurangi sampah kantong plastik. Sehingga lingkungan Kota Denpasar tetap bersih dan asri. Kepada Walikota Denpasar agar melibatkan seluruh komponen masyarakat untuk melakukan penyuluhan dan sosialisasi secara terencana, sistematis, dan masif tentang pengelolaan sampah, terutama yang berbahan dasar plastik. Hal ini penting dilakukan agar tujuan diterbitkannya Peraturan Walikota Nomor 36 Tahun 2018 Tentang Pengurangan Penggunaan Kantong Plastik dapat terwujud dengan baik.

\section{DAFTAR PUSTAKA}

Abhiseka, I. G. D., \& Suharta, N. (2018). Implementasi Peraturan Walikota Denpasar Nomor 36 Tahun 2018 Tentang Pengurangan Kantong Plastik. Kerta Negara, Vol. 7(6).

Amiruddin, \& Asikin, H. Z. (2007). Pengantar Metode Penelitian Hukum. PT Raja Grafindo Persada. Jakarta. 
Asikin, A. dan Z. (2004). Pengantar Metode Penelitian Hukum. PT Raja Grafindo Persada. Jakarta.

Gunawan. (2016). Ilmu Pengetahuan Sosial. Percetakan Pariwara. Surakarta.

Hadi, S. (1979). Metodelogi Reserch. Yayasan Penerbit Fakultas Psikologi Universitas Gajah Mada. Yogyakarta.

Hanitijo, R. (1988). Metodologi Penelitian Hukum dan Jurimetri. Ghalia Indonesia. Jakarta.

Lathif, N. (2019). Kewenangan Penyelenggaraan Program Pengurangan Kantong Plastik Di Wilayah Kota Bogor. Jurnal Gagasan Hukum, Vol 1(1).

N, K, K., \& A, A. (2020). Implementation of plastic bag reduction policy in Bogor city. Universitas Sriwijaya (UNSRI). Palembang.

Muhammad, J. (1957). Sejarah Indonesia (Cet.3). Balai Pustaka. Jakarta.

Sarwono, J. (2006). Metode Penelitian Kuantitatif dan Kualitatif. Graha Ilmu. Yogyakarta.

Syamsudin. (2007). Operasionalisasi Penelitian Hukum. PT Raja Grafindo Persada. Jakarta.

Tejo, S. (2019). Gajah laut Menagih Janji. Jawa Pos Group.Jakarta. 